\title{
Heat Shock Protein HSP 90-Beta
}

National Cancer Institute

\section{Source}

National Cancer Institute. Heat Shock Protein HSP 90-Beta. NCI Thesaurus. Code C97591.

Heat shock protein HSP 90-beta (724 aa, $~ 83 \mathrm{kDa}$ ) is encoded by the human HSP90AB1 gene. This protein plays a role in the modulation of both interferon signaling and protein folding. 